\title{
Seanchan 's Quest Restoring of the Poet's Right in Yeasts' Play The King's Threshold
}

\author{
Fawziya Mousa Ghanim
}

University of Baghdad

\section{Abstract}

William Butler Yeats (1865-1939), the prominent Irish poet and dramatist was one of the foremost figures of twentieth-century literature. He was a driving force behind the Irish Revival, and together with lady Gregory and Edward Martyn established the Abby Theatre, and served as its chief playwright during its early years. He was awarded the Noble Prize in literature for his always inspired poetry which in a highly artistic form gave expression to the spirit of a whole nation. The paper aims at analyzing the poet's quest for social freedom and poet's right in the state. The King's Threshold was first performed by the Irish National Theatre Society at the Molesworth Hall, in Dublin on 7 October, 1903. It is founded upon a MidievalIrish story of the demands of the poets at the court of King Guaire at Gort, Co. Galway; it was also influenced by Edwin Ellis's play Sancan the bard (1905) which was published ten years earlier, by Edwin Ellis.

Keywords: Seanchan, The King's Threshold, W.B. YeatsThe King's Threshold

\section{Introduction}

In this play, Yeats dramatizes the agony of a poet, who tries to save the poet's right in a world of materialistic power. By fasting, Seanchan (pronounced Shanahan), the hero shows the intrinsic elements of his quest and he fights strongly without any hesitation.

Seanchan takes his stand on the King's threshold with the intention of starving himself to death rather than submitting to "a dictate of the King that he must yield his traditional place of the honor at the great council of state".1 The plot of the play consists of a series of persuaders, who try to convince Seanchan in order to give up his quest, they are, the King, the Mayor, the lord high Chamberlain, a monk, a solider, the princess, the Girls, the two cripple men and his beloved Fedelm. They are representatives of the whole society with their various claims of compromise. They try to argue with him to make him surrender but they fail.

The pressure is so hard upon him, but he defends his claims seriously, except for a while of near-surrender to his beloved, then he insists to gain the poet's freedom even 
if it was followed by death. The poet's question is elevated by Seanchan's death, whereby it, he achieves his spiritual victory upon the authority of the King.

Moreover, the poet's pupils at the end, have the ability to grasp their master's cause, "Die Seanchan, and proclaim the right of the poets"2 (p.140). Dorothy Hoarce remarks that The King's Threshold symbolizes "the conflict between wordly power and poetry and the ultimate triumph of the poet".2 Ultimately, Yeats's hero struggles against the trivilities of the material world. The chief poet pleads "the poet's right established when the world was first established" (p.109). He cannot yield without deceiving all the poets, who are yet to be. Harold Bloom says that

the poetry connate with the origin of man, gives to mankind the institutions of laws, and the founders of civil society, and the inventors of the art of life. 3

In The King's Threshold, Yeats fights for a place of art in society through a course of debates between the bard Seanchan and characters from all ranks of society, Seanchan tries to prove that a seat at the King's table is worthier than a gift of hands and money from the king, and even than the sorrow his death would give his mother and father. The poet pursues freedom from control and aims at freedom to control, in other sense, the poet looks for freedom from political control, and wishes to obtain his liberty under the artistic power. The poet stands fast against the limitation of human world, he is not only affirms his role, but he also regards his quest as a sacred mission he wants to reach everybody and to show that poetry's concern are greater than kings, bishops, soldiers and young girls or even young poets concern, he succeeds in elucidating its superiority. The individual will succeeds in overcoming institutional authority by "the poet's supra-individual vision".4

The king expresses his detest and irritation of Seanchan's fasting; "He has chosen death/Refusing to eat and drink/That he may bring/Disgrace upon me" (p.108), if Seanchan is dead at the steps of the king's threshold, the common people will raise a heavy cry against that threshold "Even though it be the king" (p.104). The oldest pupil urges that his master chooses death "for a light issue" (p.108) Seanchan's privilege is denied by the king, and he is treated in a degrading way;

King: Three days ago

I yielded to the outcry of my courtiers -

Bishops, Soldiers, and Maker of the law -

Who long had thought it against their dignity

For a mere man of words to sit amongst them

At the great council of the state and share

In their authority. I bade him go, 
The King's power is threatened by Seanchan's 'wild thought' and 'proud will'. The king compares his own institutional bond to an archic sublimity of verse5, as he addresses Seanchan:

King: But I that sit a throne,

And take my measure from the heads of the state,

Call his wild thought that overruns the measure. (p. 110)

Seanchan's poetic thought is "measureless breaking through all form, and thus dangerous to the hirarichies of state. His laughter is an energy that defies all boundaries, even the final boundary of death".6 The king tries to offer Seanchan "a house with grass and tillage land, / An annual payment jewels and silken wear, / or anything," (p.110), instead of the old right of the poets. The bard, Seanchan reminds us that 'the images' are like "venerable things / God gave to men before He gave them wheat" (p.112). in Nietzchen's term:

The poet makes human perfection that show people the limits of the possible; without such images, future humanity would be disadvantaged, like the cripple who lingers on stage in Yeats's plays.7

Seanchan's starvation is striking proof that man lives by more than bread. He believes that destruction and calamity lead inevitably to rebirth; "when all falls / In ruin, poetry calls out in joy, / God's laughter at the shattering of the world." (p. 115). This kind of confidence "belongs to the imagination which envisions history as a cycle of rebirth, whose constant power is the eternal soul".8 Poetry according to Seanchan's belief prospers on sorrow and ruin, by the transcendental power of poetry, man can turn defeat into victory. The poet gains a spiritual victory that is beyond the reach of time.

Poetry is a mixture of "the fragile, and mighty things of God" (p.113), as Seanchan sees it, he reminds his oldest pupil "At candlemas you called this poetry/One of the fragile mighty things of God/That die at an insult" (p.113). these lines can be expressed by two levels, for those who believe poetry is fragile do not believe it can ever be mighty or vice versa. Seanchan's action is the living source of this image. He is fragile enough to die and mighty enough to triumph over the power of the king.

The position of a poet and his art is shown in two points of view, one of them is adapted by Seanchan and his revolutionary quest, the other one is expressed by the Chamberlain, who is a poet of a sort. A. S. Knowland assumes that "Yeats is able to heighten the contrast between those who pay lip-service to poetry, and those whose dedication to it is uncompromising and total".9 Ultimately, the hero defends his attitudes and ideas in his conversation with the Chamberlain who thinks that Seanchan longs for what is unusually, and describes Seanchan as a thief who "has roused the common sort against the king/And stolen his authority", in addition "That 
it is men of law/leaders of the king's armies and the like/That should sit there" (p.126), Seanchan has answered him that:

Somebody has deceived you,

In making it appear that I was driven

From the great Council. You have drive away

The images of them that weave a dance

By the four rivers in the mountain garden.

Chamberlain: You mean we have driven poetry away.

But that's not altogether true, for I,

As you should know, have written poetry.

...Is not to be compared with yours; but still,

Where I am honored poetry, in some measure,

Is honored too. (pp.127)

In driving Seanchan from the council, the king has driven out the creative imagination. The poet invites the Chamberlain to join him in his protest until the king restores the poet's ancient right, but he receives no answer. The Chamberlain cannot afford to give up the prudent virtues, and he advises Seanchan to eat something because "he [has] had these thoughts from lack of food, /For hunger makes us feverish" (p.128). Seanchan-Chamberlain's speech is finished by the brilliant and the memorable lines that are spoken by Seanchan. He compares himself and other poets with "a great wind that turns out of the waste/To blow the tables flat; and there upon/lie down upon the threshold till the king/Restore to us the ancient right of the poet's" (p.128). Yeats dramatizes Seanchan's character in his fight against three powers, the state represented by the king, and his council, the church represented by the Monk and finally the society which is represented by different kinds of people, such as the two cripples, the brain, and the Girls. He resists the rigidity of all these institutions, and declares bravely for the poet's right and spiritual freedom.

The appearance of the Monk reflects the authority of the church and its authoritive power upon mankind, and his freedom. The Monk is the mouth piece of the religious system. He regards Seanchan as a man of trouble, who will destroy the peace of the society: "If pride and disobedience are unpunished \who will obey?" (p. 123)

The Monk believes the poet's proclamation as a kind of disobedience, because Seanchan's quest is against the authority of the church and state. Seanchan longs for the high endeavor of art, especially, when the poet has a crucial position in the society, which gives him the power to charge, to purge the mind of the public. The Monk is irritated by the pride of the poets, which leads the country into chaos. 
Before his death, Seanchan delivers his message that the world of the king is corrupted, even the nature is also polluted, then he will mock the present life, especially when he will find his final reconciliation in death, "I will mock and mock that image yonder, /That evil picture in the sky - no, no! /I have all my strength again I will out face it $/ 0$, look upon the moon that's standing there /In the blue day light, ...because it is the white of leprosy" (p.141). F.A.C. Wilson asserts that the leprosy suggests the contagion of a philistine society with a tamed god, which replaces the older with its Dionysiac ethos.10 Seanchan's triumph is expressed when he faces death with a laughing face, "king! King! Dead faces laugh" (p.141), he dies with an unusual victory over the passivity of life. Barto R. Friedman points out that the hero by dying rises into a myth, from the ruin of time he builds a mansion in eternity.11The play ends by Seanchan's funeral, when his pupils take up his body and cry loudly that "he seeks high waters and the mountain birds" (p.142), and they "will bless what he has blessed/And curse what he has cursed" (p.143). The trumpets that declare the death of Seanchan will be spread everywhere, and will announce the rebirth of the coming of the great race;

Youngest pupil: O, Silver trumpets, be you lifted up

And cry to the great race that is to come.

Long-throated swans upon the wave of time,

Sing loudly, for beyond the wall of the world

That race may hear our music and awake. (p143)

Seanchan becomes a pioneer of civil fortitude, by his starvation, he raises the slagon of the poet's right. He is distinguished as a leading figure in his society his essential role is to defend poetry and path the way towards purified art. Poetry should be authoritive power like the authority of the state, the poet is like any member of the king's council, he should have the same position and power. Indeed, the poet should have been treated not as a man of mere words, because "God gave [the words] to men before he gave them wheat" (p112). In The King's Threshold, Yeats says that the civility of any society is elevated, when the position of poet and poetry is elevated too. The poets are the makers of beauty, love, and intellectuality.

\section{Conclusion}

Seanchan's actual life can be attained only when he finds his dream come true. This transcendental truth can be retained by his self-sacrifice, which liberates art and man from superficiality. By his practical action, he is a teacher, who gives a moral and spiritual lesson. The poet cannot live in between or as a shadow. He is the creator of art and civility. Seanchan's claim is an ancient one, he looks for a new kind of order and reality. The poet dies, but his claim is undefeated; he and his visions are glorious. 


\section{Bibliography}

[1] A.S. Knowland, Yeats: Dramatist of Vision (Totoway: Barnes and Noble Books, 1983), p. 29.

[2] Adrian Frazier, Behind the Scenes: Yeats Horniman, and the Struggle for the Abbey Theatre, (Berkeley: University of California Press, 1990), p. 97.

[3] Andrew Parkin, The Dramatic Imagination of W.B. Yeats, (New York: Barnes \& Noble Books, 1978), p. 90.

[4] Dorothy Hoarce, The Work of Morris and Yeats in Relation to early Sage Literature, (Cambridge: Cambridge University Press, 1937) p. 120.

[5] F.A.C. Wilson, W.B. Yeats and Tradition (London: Methuen and Co. Ltd., 1968), p.91

[6] Harold Bloom, Yeats, (London: Oxford University Press, 1970) p. 149.

[7] James W. Flannery, W.B. Yeats and the Idea of a Theatre, (London: Yale University Pess, 1976), p. 301.

[8] John Rees Moore Masks of Love and Death: Yeats as Dramatist, (New York: Corneil University Press, 1971) p. 89.

[9] John Rees Moore, p. 100

[10] R. Jahan Ramazni, "Yeats tragic joy and the sublime" PMLA, vol.104, No.2 (March 1989) p. 174.

[11] W.B. Yeats The Collected Plays of W.B.Yeats, (London: Macmillan \& Co. Ltd., 1982). All references to Yeats's plays are taken from this edition, p. 151. 